\title{
Learners' Attitudes toward Foreign Language Practice on Social Network Sites
}

\author{
Jhonny Villafuerte ${ }^{1,3} \&$ Asier Romero $^{2}$ \\ ${ }^{1}$ Fellow SENESCYT Ecuador, Doctorade Program of Psychodidactics, University of the Basque Country, \\ Basque Country, Spain \\ ${ }^{2}$ Department of Language and Literature Didactics, University of the Basque Country, Basque Country, Spain \\ ${ }^{3}$ University Laica Eloy Alfaro de Manabi, Manta, Ecuador \\ Correspondence: Jhonny Villafuerte, Universidad Laica Eloy Alfaro de Manabi, Manta, Ecuador. Tel: \\ 593-99-821-9014. E-mail: jhonny.villafuerte@gmail.com
}

Received: April 25, 2017

Accepted: June 15, 2017

Online Published: June 28, 2017

doi:10.5539/jel.v6n4p145

URL: http://doi.org/10.5539/jel.v6n4p145

\begin{abstract}
This work aims to study learners' attitudes towards practicing English Language on Social Networks Sites (SNS). The sample involved 110 students from the University Laica Eloy Alfaro de Manabi in Ecuador, and the University of the Basque Country in Spain. The instrument applied was a Likert scale questionnaire designed Ad hoc by the researchers, to assess the dimensions: (i) Integration of SNS into learners' academic everyday activities, and (ii) Learners' attitudes towards English Language practices on SNS. All the data was analyzed using SPSS V24.00 of IBM. The findings showed corelationships between learners' attitudes and the factors: learners' sex, age, and country. The results also confirmed that both Spanish and Ecuadorian university students prefer YouTube, and Google+ for their easy access, and flexibility to strengthen listening, reading and comprehension skills in English. In addition, Facebook, and Whats App can be used to motivate reading, writing, and speaking practices in English.
\end{abstract}

Keywords: English language, information and communication technology, learners' attitudes, higher education, universal education

\section{Introduction}

Learners' attitudes towards foreign language practices are part of the existing debate about the real contribution of Information and Communication Technologies (ICT) on Educational Systems around the world, and implications for the success of the present and future learning processes (Piccoli, Ahmad, \& Ives, 2001). Thus, Social Networking Sites (SNS) are studied as tools that have the power to generate changes in the way how people interact with each other (Boyd \& Heer, 2006), using diverse formats like: texts, images, and sounds (Beck, 2007).

However, it is necessary to transform current teaching practices (Coll, Mauri, \& Onrubia, 2008) to motivate university students to assume their role as autonomous learners. SNS allow learners to produce their own content (Cabero, 2009) and practices. Such active participation stimulates learners' creativity and collaborative abilities (Esteven, 2009) during their studies.

Studies reveal that, the increasing availability of technological resources in educational institutions does not necessarily imply a significant modification of the traditional teaching models (Area, 2010); rather, teachers and students require of strategies to promote their own "learning to learn" abilities (Burgues, 2011) because "we participate, therefore we are". So, "that equilibrium results to be the most adequate perspective for the learning process of the current age of digital innovations" (Seely, 2012, p. 15).

Having in mind the Global Sustainable Development Agenda by 2030 (UNESCO, 2015), and the hope for giving a contribution to the project for the "Universal, Inclusive, and Indivisible Educational System", scholars consider the integration of "ICT" into educational, as a positive step to improve current educational systems (Schalk, 2010).

This research takes place in Spain and Ecuador, countries where it is possible to find pluri-language communities (Spanish, Catalan, Galician, and Euskara languages in Spain; and Castilian, Kichwa, and Cayapa languages in Ecuador). To have a "proficiency in English" is considered for Spanish and Ecuadorian population as a key 
knowledge to improve their access to the newest technology, guarantee their participation in cultural and economic international exchanges (Esteve, 2009; Gobierno de Ecuador, 2011) and, it is a current key competence to get new or better employment.

In the case of Spain, European Commission (EC) during the period 2006 to 2010, launched a group of experts on media literacy to encourage EU Members to begin a debate on the possible inclusion of media ICT in the compulsory education curriculum (Aguaded, 2013). Also, the Bologna Process for the European Higher Education Area established standards, and competences to be reached for every professor and pupil in the European Educative Space (European Commission/EACEA/Eurydice, 2015).

In the case of Ecuador, the Organic Law for Higher Education (2011) established international standards that the institutions, professors, and students should reach in the middle term. The "Consejo de Educación Superior" (CES) has as mission to monitor, and evaluate every higher education institutions located in the territory to warranty education of quality to all the population. However, despite of the current Ecuadorian government investment on technological equipment instalation, professors training, research projects, etc., the digital education development in Ecuador is still slow (Villafuerte, Carreño, \& Demera, 2015). For that reason, it is necessary support learners to assume their position as active constructors of their own knowledge thus, Fernandez and Torres (2015) argue that, the correct way is to increase learners' direct, and interactive contact with the community, and the searching for new evaluation process. In addition, "Websites and resources that involve interaction (chat-rooms, wikis, blogs) in the Internet should be encouraged and made clear to the learners as complementary for language learning. As for academic writing, mostly reflected as an essay" (Cevallos, Intriago, Villafuerte, Molina, \& Ortega, 2017. p. 111).

The goal of this work is to study Spanish and Ecuadorian learners' attitudes toward English Language practice on Social Network Sites.

\subsection{Learners' Attitudes and Social Network Sites}

The term "attitude" is defined by Fasol (1985) as the "mental response to a given situation". Such attitudes are highly relevant for the success of educational projects so, "a more positive learners' attitude toward ICT will result in more satisfied effective learning using e-Learning environments" (Piccoli et al., 2001).

Learners' attitude towards ICTs can be also defined as: learners' impression from participating in activities developed on computers (Sun, Tsai, Finger, Chen, \& Yeh, 2007). Thus, positive attitudes have the power to increase learners' chances of success when they use computer devices in their diverse academic works. On the other hand, negative attitudes reduce students' interest and chances to complete successful learning activities. So, attitudes "influence our perception of the world around us, and determine how we respond to different entities of the world" (Farhat \& Kazim, 2011, p. 604) in special, if these are related to the acquisition of new knowledge, experiential, and ideational levels in the higher education context (Halliday, 2014).

Barry Wellman (1996, p. 1) referring to "Social Network Sites" argued that "a computer network connects people (or organizations or other entities) by a set of socially meaningful relationships [...] like: strong affect, mobility, happiness, work habits, and many other important things about them". Boyd and Ellison (2008) defined SNS as "web-based services that allow individuals to (1) construct a public or semi-public profile, (2) articulate a list of users to share connections, and (3) view other users list of contacts within the internet system" (p. 2).

To Jansen (2010), quoted in Martensen, Börgmann, and Bick (2011), SNS is a kind of "web of social relations in which individual, group, collective or corporate actors are embedded" (p. 243). Thus, people exchange information using multiple devices, and computer applications like chats (conversation on line), exchange of photography and video material, music, or other different information media devices (Reed et al., 2010).

Scholars around the world have also introduced the term "Social Networking Sites" to approach the study of this social phenomenon. Thus, Ateeq Ahmad (2011) from India refers to "Social Networking Sites" as informatics platforms that allow people access to users' sources of data, networks, contacts, and other business information. Also, Temprano (2011) refers to SNS as informatics applications that allow users to interact with one another, without being necessary to install any new software in the equipment. SNS can be used in different areas of any educational system, including academic monitoring, administrative procedures, and other supportive areas (Ricoy $\&$ Couto, 2012), they offer to learners the opportunity to construct or create new knowledge with others; even though, students do not really know how to use SNS in academic work (Kirschner, 2015, p. 3) because, traditionally these media have been only used for social information exchange but, SNS also should be researched as a tool to improve learners' academic achieves. 


\subsection{The Origen and Evolution of Social Network Sites}

To Boyd and Ellison (2008), the first social network site was launched in 1997. They refer to "SixDegrees.com" which allowed to creat users' profiles. So, people could watch their friends' data list by screens. After the year 2000, the "Ryze, Tribe.net, and Friendster" were launched as informal social networks, and "LinkedIn" as a social network for professional communication.

"QQ" started as a Chinese instant messaging service; "LunarStorm" began as a community site; "Cyworld" was a Korean discussion forum tool; and "Skyrock" (formerly Skyblog) was a French blogging service, until it added SNS features. The "Classmates.com" was a directory of school students. It was launched in 1995 to give support to their members but, it became in a popular SNS. The "AsianAvenue"; "MiGente"; and "BlackPlanet" were early popular ethnic community sites with a limited number of participants, before their re-launching on SNS structure during 2005-2006.

In 2004, Mark Zuckerberg, Eduardo Saverin, Chris Hughes, and Dustin Moskovitz introduced "Facebook" as an academic network for Harvard students. Now, it has become the most popular social network in the world, followed by YouTube which was introduced by Chad Hurley, Steve Chen, and Jawed Karim in 2005. YouTube allows users to create a channel, and upload home videos about different themes, which can be followed by other YouTube users (YouTubers) around the world.

In 2006 appeared "Twtrr", later renamed as "Twitter". This was a blog project of Evan Williams (creator of Google), Dom Sagolla, Jack Dorsey, and other technology entrepreneurs. This service is a "Nanoblogging" tool that allows users, to send SMSs to several other users at the same time. In 2007 the blog Interactivity.org mentioned that Twtrr has won the "South by Southwest Award" in the category blog, and it became a very popular social network in the following years.

Brian Acton y Jan Koum introduced "WhatsApp" in 2008 as a pictures application. It showed its great potentialities as a social network the four years after, when it allowed users to exchange pictures as part of the instant communication process. In 2010, Kevin Systrom and Mike Krieger centred multiple functions of HTML5 in a mobile picture project. Apple App Store launched this under the name of "Instagram" (Gonzalez, 2012). The same year, "Snapchat" was developed by Evan Spiegel, which got impulse after 2012 because its multiple resources.

Mark Zuckerberg published in 2009 that Facebook had gotten more than 350 million users around the world, but for 2013, WhatsApp had more than 400 million users. Facebook bought "WhatsApp" in 2014 for 21.000 million dollars. For the protection of users' identity, wer developed: the android's system, and the "point-to-point" encryption system (Sainz, 2014).

Finally, from 2016 users can make videocalls on a smartphone and other mobile devices using WhatsApp or Facebook. The lenses for "Selfies" caused sensation among the users of "Snapchat", reaching 200 million users around the world in 2015. It also registered 7.000 million views of videos per day, in January 2016 (Vaynerchuck, 2016). These are facts that show the evolution of the SNS and their level of acceptation around the world.

\subsection{Expansion of Social Networks Sites}

The use of non-genuine pictures, false names, and ages; the frequency of offensive language; and the possible presence of sexual predators, were the cuases for "SNS users' panic" observed during the years 90s (Bahney, 2006). However, the rapidly increase of users' interest on Internet generated a high transit of information on the electronic platforms (Boyd \& Heer, 2006). Users adopted the culture of on line identity-protection, and antiviruses softwares management, as strategies to reduce cyber risks such as computer frauds, and cyber bullying. So, the popularity of websites, blogs and SNS continued in progress. At the beginning of the $21^{\text {st }}$ century, 2.17 billion people had accessed to Internet but, it depends of government policies, socioeconomical priorities, and technical conditions of nations around the planet (Armstrong \& Franklin, 2008).

Jose Faccin (2016), based on a review of several statistics suppliers, argued the most important Social Network Sites in the World for the category "SNS of general interest" are: Facebook (1.700 million users), Twitter (500 million users), Google+ (500 million users), Myspace (38 million users), and Ning (10 million users).

For the category "SNS accessed by Mobile phones" appeared: Cellufun, MocoSpace, and Itsmy. Finally, for the category "SNS used to watch videos" appeared: Stickam, Funnyordie, and YouTube.

Social Network Sites allow students to stablish "relationships between the contains, and situations of daily life" (Salinas, 2001, p. 41), condition that is considered as fundamental for adults learning on higher education systems. However, experience has taught about the necessity of stablishing respect policies, and general rules to follow 
when people is part of a cyber community. The goal is to reach relevant levels of trust, reciprocity, and tolerance between SNS members, as values for good coexistence (Cabero, 2005). Such kind of social dynamic interactions are immersed in the construction of a group identity known as "social learning" (Muro \& Jeffrey, 2008) meanwhile, the frequency and time of learner's participation on SNS around the world would depend of the available technology, lecturers' SNS training, learners' compromise, and institutions priorities (Armstrong \& Franklin, 2008). In addition, lecturers have used online resources during decades to "enhance teaching practices, because of the affordances that it offers, or because students are already using ICT" (Armstrong \& Franklin, 2008, p. 1). However, it is necessary to recognize that didactics for -education supported on computers- require the transformation of current teaching practice to improve the classrooms efficiency (Coll, Mauri, \& Onrubia, 2008).

In the field of foreign language teaching, computers enable learners to work with sophisticated and abundant video, and audio resources (Temprano, 2011). These experiences lead participants to develop new skills, attitudes, and competences (Thomas \& Brown, 2011) for the practice of a foreign language.

So, the use of ICT can be a key partner to form healthy, creative, interactive and committed citizens (Fernandes \& Bermejo, 2012). But, it is necessary remark that, it is an error to repeat teaching old strategies using new ICTs environments (Ricoy \& Couto, 2012).

Nadkarni and Hofman (2012) argued that SNS as Facebook facilitate narcissism attitudes in students, reducing their potentialities for the social knowledge construction. Other scholars as Cabero and Barroso (2013) argued SNS have contributed overcoming the space barriers and have promoted the strengthening of collaborative learning in academic contexts. Also, Maiz and Tejada (2013) argue that the objective of Social Networks Sites looks to improve communication and transmission of information between learners in multiple ways of interaction.

In addition, the catalytic effects of SNS have generated in students: greater independence and autonomy learning, more collaborative attitudes, and improvement of-efficiency of vocational training programs (Zapata-Ros, 2014); those impacts become more relevant when, policies of lifelong learning are associated to the changing of labour markets (Fernandes \& Torres, 2015). However, there are scholars who have a different position on the effectiveness of SNS on educational practice. In the Netherlands, Greenhow, Menzer, and Gibbins (2015); and Asterhan and Hever (2015) argue that, people is not expecting to find in SNS new opportunities to discuss about a scientific topic. In this same line of research, Kirschner (2015) affirms that "there is a long road to travel down before SNS like Facebook can be effectively and efficiently used as tools for knowledge construction, and knowledge creation" (p. 4). However, Lucas and Moreira (2015) argue educational interventions on SNS have developed "civic and citizenship attitudes, especially the ability to accept the diversity and the difference" (p. 8) in the asset for the construction of collaborative work environments.

Previous studies of Sun, Tsai, Finger, Chen, and Yeh (2007) about Asian Learners and ICT interactions, reveals that the critical factors affecting learners' satisfaction are: learners' anxiety before the computer, instructor attitude toward e-Learning, e-Learning course flexibilities, e-Learning course quality, ICT usefulness perceived, difficulty level perceived, and assessments diversity. Finally, Farhat and Kazim (2011) found in the Indian Government College University Faisalabad (GCUF) that, learners have an overwhelmingly negative attitude towards the teaching foreign language culture, since the study of the dimensions: beliefs, customs, social organization, gestures, and notions of personal space.

\subsection{State Hypotheses and Their Correspondence to Research Design}

This work is focus on learners' attitudes towards language practice on SNS.

The hypotheses studied in this work are:

(i) Spanish and Ecuadorian students prefer the same SNS for their foreign language practices.

(ii) The use of SNS for the language practice offers to learners the access to more diverse and realistic learning.

(iii) Using SNS on language practice improve learners' motivation for acquiring a foreign language.

The questions to answer are:

How are university students' attitudes towards social networks sites? What correlationships exist between the students' attitudes for English Language practice on SNS, and learners' factors age, sex, and country? 


\section{Method}

This is a quantitative research. It was administrated a Likert scale questionnaire developed by the researchers' team to determine, the learners' attitudes towards English Language practice on Social Network Sites. Authors consider "foreign language acquisition process" as an "empirical phenomenology" of the educational field.

\subsection{Identify Subsections}

Activities concerned to the empirical study were organized as follows:

Step (i): Use of Social Network Sites (SNS) as academic tool. A trend analysis related to learners' use of SNS on everyday academic activities, and specifically on English Language practice. Measure applied is central tendency index.

Step (ii): Social Network Sites that learners prefer for their English Language practice. The SNS preferred by European (Spain) and South American (Ecuador) learners, for their English Language practice. Function applied is table of frequency.

Step (iii): Determination of Factorial and Multiple factorial relationships. Analisys of the relationships between the factors: Learners' sex, age, and country with the items of the questioner: "Learners' attitudes toward English language practices through Social Network Sites". The index applied are Chi-Square of Pearson and ANOVA.

\subsection{Participants}

The sample involved 120 learners, 40 students ( 28 women and 12 men) regularly attending to the Program School of Teaching at the University of the Basque Country (EHU), campus Bilbao, Spain; and 80 students (47 women and 33 men) from the Faculty of Education at the University Laica Eloy Alfaro de Manabi (ULEAM), campus Manta, Ecuador.

Table 1. Sample, learners from EHU and ULEAM

\begin{tabular}{|c|c|c|c|c|}
\hline Factors & & Categories & $\mathrm{N}$ & \\
\hline \multirow[t]{3}{*}{ Students' sex: } & & Female & 75 & \\
\hline & & Male & 35 & \\
\hline & Total & & & 110 \\
\hline \multirow[t]{6}{*}{ Students' age: } & & Younger than 20-year-old & 2 & \\
\hline & & 21-25 year-old & 78 & \\
\hline & & 26-30 year-old & 13 & \\
\hline & & 31-35 year-old & 7 & \\
\hline & & Older than 36-year-old & 10 & \\
\hline & Total & & & 110 \\
\hline \multirow[t]{6}{*}{ Students' countries: } & & Spain: EHU Pre school & 16 & \\
\hline & & Spain: EHU Elemenary Ed. & 16 & \\
\hline & & Spain: EHU Other programs & 8 & \\
\hline & & Ecuador: ULEAM F. Language & 35 & \\
\hline & & Ecuador: ULEAM O. programs & 35 & \\
\hline & Total & & & 110 \\
\hline
\end{tabular}

Source: Students attendance registers at EHU and ULEAM (2016).

Note. EHU = University of the Basque Country, Spain; ULEAM = University Laica Eloy Alfaro of Manabi, Ecuador.

\subsection{Measures and Covariates}

The questionnaire applied in this work was "Attitudes for language practices through Social Network Sites" which was developed ad hoc, by the researchs' team. 
This instrument consists of a card of participants' data (sex, age, university, study program, and disability -if it is the case-).

The Likert questionnaire consists of 30 items organized as follow: 10 items in the first dimension: "The students' use of Information and Communication Technologies (ICT) in their everyday academic activities", and 20 items in the second dimension: "Social Networks Sited preferred by students for their English language practices".

The result of the "Cronbach's Alpha" test was $=0.84$ for all 30 items, which responds positively to international reliability and reliability standards.

The variable studies are: Learners' sex, age, and country.

\section{Results}

\subsection{Learners' Acceptance of Social Network Sited (SNS) as Academic Tool (i)}

The data shows how participants use SNS in their academic activities. It exists a positive learners' acceptance of SNS as academic tool.

Table 2. Learners' use of Social Network Sites in everyday academic activities

\begin{tabular}{|c|c|c|c|c|c|}
\hline Dimension 1: Integration of SNS into academic activities & $\mathrm{N}$ & Mín. & Max. & Sum & Average \\
\hline 1.1) I think it's easy to use social media. & 110 & 1 & 6 & 569 & 5.17 \\
\hline $\begin{array}{l}\text { 1.2) I think I know perfectly well how to use the social networks like Facebook, } \\
\text { YouTube, WhatsApp. }\end{array}$ & 110 & 1 & 6 & 543 & 4.94 \\
\hline $\begin{array}{l}\text { 1.3) I think I do not need tutorials or help to use social networks Facebook, } \\
\text { YouTube, WhatsApp, and Twitter. }\end{array}$ & 110 & 2 & 6 & 490 & 4.45 \\
\hline $\begin{array}{l}\text { 1.4) I think I could upload any kind of file to social networks (videos, photos, } \\
\text { etc.) }\end{array}$ & 110 & 1 & 6 & 488 & 4.44 \\
\hline $\begin{array}{l}\text { 1.5) Social networks sites like Facebook, YouTube, WhatsApp, Twitter, etc. } \\
\text { Facilitate contact with other people. }\end{array}$ & 110 & 1 & 6 & 611 & 5.55 \\
\hline 1.6) I think social networks will hardly be replaced by other computer tools. & 110 & 1 & 6 & 523 & 4.75 \\
\hline 1.7) I feel that social networks make me waist my study time. & 110 & 1 & 6 & 432 & 3.93 \\
\hline $\begin{array}{l}\text { 1.8) I think that university students do use the functions offered by social } \\
\text { networks in multiple educational activities. }\end{array}$ & 110 & 1 & 6 & 557 & 5.06 \\
\hline $\begin{array}{l}\text { 1.9) I think that Facebook fosters creativity in college students better than any } \\
\text { other social network. }\end{array}$ & 110 & 1 & 6 & 348 & 3.16 \\
\hline $\begin{array}{l}\text { 1.10) I think college students only use Facebook to get non-academic } \\
\text { information. }\end{array}$ & 110 & 1 & 6 & 388 & 3.53 \\
\hline $\mathrm{N}$ & 110 & & & & \\
\hline
\end{tabular}

Made by: Researchers team (Oct. 2016).

Observe the average level reached in the following items:

1.1) I think it's easy to use social media: 5.17 points average.

1.2) I think I know perfectly well how to use the social networks like Facebook, YouTube, WhatsApp: 4.94 points average.

1.5) Social networks sites like Facebook, YouTube, WhatsApp, Twitter, etc. Facilitate contact with other people. 5.55 points average.

1.8) I think that university students do use the functions offered by social networks in multiple educational activities: 5.06 points average.

Students also demonstrated disagreement in item referring "social networks as elements of distraction for the academic work".

1.7) I feel that social network Sites make me waist my study time: 3.93 points average. 
1.10) I think college students only use Facebook to get non-academic information: 3.53 points average.

Table 3. Use of SNS for English language practice

\begin{tabular}{|c|c|c|c|c|c|}
\hline Dimension 2: English Language Practice on Social Networks Sites & $\mathrm{N}$ & Mín. & Max. & Sum & Average \\
\hline $\begin{array}{l}\text { 2.1) Social networks sites because their functionality should be used for } \\
\text { English language practice in higher education. }\end{array}$ & 110 & 1 & 6 & 488 & 4.44 \\
\hline $\begin{array}{l}\text { 2.2) When I must study for an English language exam, I prefer to practice } \\
\text { using on line software. }\end{array}$ & 110 & 1 & 6 & 389 & 3.54 \\
\hline 2.3) Social networks sites help me in my grouped study. & 110 & 1 & 6 & 437 & 3.97 \\
\hline $\begin{array}{l}\text { 2.4) Social network sites I would use for practice English language is } \\
\text { YouTube. }\end{array}$ & 110 & 1 & 6 & 478 & 4.35 \\
\hline $\begin{array}{l}\text { 2.5) Social network sites I would use for practice English language is } \\
\text { WhatsApp. }\end{array}$ & 110 & 1 & 6 & 323 & 2.94 \\
\hline $\begin{array}{l}\text { 2.6) Social network sites I would use for practice English language is } \\
\text { google+. }\end{array}$ & 110 & 1 & 6 & 386 & 3.51 \\
\hline $\begin{array}{l}\text { 2.7) Social network sites I would use for practice English language is } \\
\text { Facebook. }\end{array}$ & 110 & 1 & 6 & 350 & 3.18 \\
\hline $\begin{array}{l}\text { 2.8) I rarely find useful things on Facebook to help me study for my English } \\
\text { exams. }\end{array}$ & 110 & 1 & 6 & 498 & 4.53 \\
\hline $\begin{array}{l}\text { 2.9) The informality of English used on Facebook and YouTube could be } \\
\text { detrimental in the preparation of language exams. }\end{array}$ & 110 & 1 & 6 & 398 & 3.62 \\
\hline $\begin{array}{l}\text { 2.10) For a college student Facebook is more a distraction, because all it } \\
\text { offers }\end{array}$ & 110 & 2 & 6 & 496 & 4.51 \\
\hline 2.11) I like to practice Phonics in English using on line programs & 110 & 1 & 6 & 423 & 3.85 \\
\hline $\begin{array}{l}\text { 2.12) My oral expression in English would be better if I would practice using } \\
\text { social networks video conferences. }\end{array}$ & 110 & 1 & 6 & 499 & 4.54 \\
\hline $\begin{array}{l}\text { 2.13) I like reading blogs in English language because people express their } \\
\text { ideas in a natural way. }\end{array}$ & 110 & 1 & 6 & 456 & 4.15 \\
\hline $\begin{array}{l}\text { 2.14) I feel my fluency in English progresses when I practice using forums in } \\
\text { the social networks. }\end{array}$ & 110 & 1 & 6 & 421 & 3.83 \\
\hline 2.15) I like the computer corrects my spelling in English language. & 110 & 1 & 6 & 589 & 5.35 \\
\hline $\begin{array}{l}\text { 2.16) I feel that when I practice English using videos available on social } \\
\text { networks, I improve my understanding in that language. }\end{array}$ & 110 & 1 & 6 & 532 & 4.84 \\
\hline $\begin{array}{l}\text { 2.17) Facebook has applications that can help me to improve my oral } \\
\text { expression in English. }\end{array}$ & 110 & 1 & 6 & 410 & 3.73 \\
\hline 2.18) I can find in Facebook much material to practice reading in English & 110 & 1 & 6 & 390 & 3.55 \\
\hline $\begin{array}{l}\text { 2.19) It is possible to watch and listen videos in English about current topics } \\
\text { on Facebook. }\end{array}$ & 110 & 1 & 6 & 447 & 4.06 \\
\hline $\begin{array}{l}\text { 2.20) If want people understand my messages in English, I must check } \\
\text { very well my spelling before to uploading it to Facebook. }\end{array}$ & 110 & 1 & 6 & 543 & 4.94 \\
\hline N. & 110 & & & & \\
\hline
\end{tabular}

Made by: Researchers team (Oct. 2016).

Participants answered the Items since their conviction about SNS facilitate contact with English speaking people. 1.5) Social networks like Facebook, YouTube, WhatsApp, Twitter, etc. Facilitate contact with other people: 5.55 points average. 
2.15) I like the fact that the computer corrects my spelling in English: 5.35 points average.

2.16) I feel that when I practice English using videos available on social networks, I improve my understanding in that language: 4.84 points average.

2.20) If I want people to understand my messages in English, I must check very well my spelling before uploading it to Facebook: 4.94 points average.

In addition, learners showed disagree because the SNS rarely provides formal resources for the foreign language practice.

2.8) I rarely find useful things on Facebook to help me study for my English exams: 4.53 points average.

\subsection{Determination of the SNS Preferred by the University Students for Their English Language Practice (ii)}

Learners' answered between (TD) Total Disagreement and (TA) Total Agreement to questions related to Students' SNS preference for doing their English Language practices.

Table 4. Social networks sites preferred by students for English language practice

\begin{tabular}{|c|c|c|c|c|c|c|}
\hline Items & PA & A & TA & Sum & N. & $\begin{array}{l}\text { Statistic } \\
\text { Deviation }\end{array}$ \\
\hline 2.4) The Social Network Site I prefer for my English language practice is YouTube & 28 & 21 & 17 & 66 & 75 & 9 \\
\hline 2.6) The Social Network Site I prefer for my English language practice is Google+. & 13 & 15 & 10 & 38 & 75 & 37 \\
\hline 2.7) The Social Network Site I prefer for my English language practice is Facebook & 22 & 11 & 1 & 34 & 75 & 41 \\
\hline 2.5) The Social Network Site I prefer for my English language practice: WhatsApp. & 15 & 6 & 2 & 23 & 75 & 52 \\
\hline
\end{tabular}

Note $. \mathrm{PA}=$ partially agree; $\mathrm{A}=$ Agree; $\mathrm{TA}=$ Totally agree .

Made by: Researchers team (Oct. 2016).

The results on the column "Sum" shows YouTube has obtained 66 of 75 points, therefore, the tendency is that YouTube is the SNS mostly preferred by the participants to carry out their English Language practice. Far below are Google+, Facebook, and WhatsApp.

Students of EHU and ULEAM chose YouTube and Google+ as the first and second SNS preferred for their English Language practice. About other SNS, Spanish learners (EHU) prefer more WhatsApp than Facebook, meanwhile Ecuadorian learners (ULEAM) prefer Facebook than WhatsApp for their English Language practice.

Table 5. Spanish and Ecuadorian learners' SNS preferences

\begin{tabular}{ccccc}
\hline $\begin{array}{c}\text { Social Network } \\
\text { Sites }\end{array}$ & $\begin{array}{c}\text { University of the Basque } \\
\text { Country, Spain }\end{array}$ & $\begin{array}{c}\text { University Eloy Alfaro de } \\
\text { Manabi, Ecuador }\end{array}$ & $\begin{array}{c}\text { Students } \\
\text { preferences }\end{array}$ & $\mathrm{N}$ \\
\hline YouTube. & 33 & 48 & 81 & 110 \\
Google+. & 12 & 34 & 46 & 110 \\
Facebook. & 10 & 31 & 41 & 110 \\
WhatsApp. & 11 & 17 & 28 & 110 \\
\hline
\end{tabular}

Made by: Researchers team (Oct. 2016).

\subsection{Determination of Learners' Attitudes toward English Language Practices through SNS-Factorial and Multiple Factorial Relationships (iii)}

Factorial relationships:

The hypotheses to be tested using the Chi-square of Pearson index, is:

$$
\begin{aligned}
& \mathrm{Ho}=\mathrm{X} \text { and } \mathrm{Y} \text { are independent. } \\
& \mathrm{H} 1=\mathrm{X} \text { and } \mathrm{Y} \text { are not independent. }
\end{aligned}
$$


Table 6. Relationships between Learners' attitudes toward SNS and factors sex, age, and country

\begin{tabular}{|c|c|c|c|}
\hline Items & Sex & Age & Country \\
\hline $\begin{array}{l}\text { 2.1) Social Networks Sites' functionality should be used for English language practice in the } \\
\text { higher education context. }\end{array}$ & 0.82 & 0.00 & 0.04 \\
\hline $\begin{array}{l}\text { 2.2) When I must study for an English Language exam, I prefer to practice using any "on line } \\
\text { software" }\end{array}$ & 0.99 & 0.22 & 0.04 \\
\hline 2.3) Social networks Sites help us to study in groups. & 0.81 & 0.01 & 0.02 \\
\hline 2.4) The Social Network Site I would use for practice English Language is YouTube. & 0.83 & 0.19 & 0.04 \\
\hline 2.5) The Social Network Site I would use for practice English language is WhatsApp. & 0.84 & 0.04 & 0.12 \\
\hline 2.6) Social Network Site I would use for practice English language is google+. & 0.57 & 0.00 & 0.03 \\
\hline 2.7) Social network Site I would use for practice English language is Facebook. & 0.39 & 0.28 & 0.01 \\
\hline 2.11) I like to practice Phonics in English using any "on line program" & 0.96 & 0.02 & $\mathbf{0 . 0 0}$ \\
\hline $\begin{array}{l}\text { 2.12) My oral expression in English would be better, if I would practice using SNS video } \\
\text { conferences. }\end{array}$ & 0.77 & 0.27 & $\mathbf{0 . 0 0}$ \\
\hline 2.13) I like reading blogs in English language, because people express their ideas in a natural way. & 0.12 & 0.22 & 0.02 \\
\hline $\begin{array}{l}\text { 2.14) I feel my fluency in English progresses when, I practice using forums on the Social } \\
\text { Networks Sites. }\end{array}$ & 0.83 & 0.12 & 0.00 \\
\hline $\begin{array}{l}\text { 2.16) I feel my understanding in English progresses when, I practice using videos available on } \\
\text { social networks. }\end{array}$ & 0.11 & 0.13 & $\mathbf{0 . 0 3}$ \\
\hline 2.20) I must check my spelling in English very well before, uploading any text. & 0.49 & 0.34 & 0.04 \\
\hline
\end{tabular}

Made by: Researchers team (Oct. 2016).

Learners' sex factor: all the attitudes items reported Chi-square of Pearson index $>=0.05$. Therefore, the hypothesis about the independent variables is fulfilled. So, there is no significant relationship between learners' sex and their attitudes toward English language practices through SNS.

Learners' country factor: all the attitudes items reported Chi-square of Pearson index $>=0.05$; in compliance with the hypothesis on the independent variables; except for the items: 2.1), 2.2), 2.3), 2.4), 2.6), 2.7), 2.11), 2.12), 2.13), 2.14), 2.16), and 2.20 in which, the Chi-square of Pearson index is $<0.05$. In consequence, there are significant relationships between the factor learners' country, and their attitudes towards their English practice through SNS.

Learners' age factor: all the attitudes items reported Chi-square of Pearson index $>=0.05$. Therefore, the null hypothesis is fulfilled, except for the items: 2.1), 2.3), 2.5), 2.6) and 2.11) in which, the Chi-square of Pearson is < 0.05 . Therefore, there are significant relationships between the factor Learners' age, and Learners' attitudes towards their English language practices through SNS.

\subsection{Study of the Multifactorial Relationships}

This analysis considered the Learners' factors: sex, age, and country in contrast to the dimension 2 of the Linkert questionnaire: Learners' attitudes for English language practice through Social Network Sites (SNS).

Table 7. ANOVA of the learners' factors sex, age, and country

\begin{tabular}{lccc}
\hline Items & Media square & F & Sig. \\
\hline $\begin{array}{l}\text { 2.2) When I must study for an English language exam, I prefer to practice using on line } \\
\text { software. }\end{array}$ & 8134.0 & 4532.0 & 0.07 \\
2.4) Social network site I would use for practice English language is YouTube. & 7371.0 & 5192.0 & 0.06 \\
2.15) I like the computer corrects my spelling in English language. & 8488.0 & 12579.0 & 0.05 \\
2.16) I feel that when I practice English using videos available on social networks, I & 3166.0 & 6286.0 & 0.09 \\
improve my understanding in that language. & & 4058.0 & 0.09 \\
2.17) Facebook has applications that can help me to improve my oral expression in English. & 5524.0 & 5196.0 & 0.05 \\
2.19) It is possible to watch and listen videos in English about current topics on Facebook. & 8447.0 & 17187.0 & 0.00 \\
2.20) For people to understand my message in English on Facebook, I must check it very \\
well before uploading it.
\end{tabular}

Made by: Researchers team (Oct. 2016). 
The ANOVA index shows that Ho (Null hypothesis) is rejected, based on the significance degree value which exceeded to 0.05 ; except in the items 2.2), 2.4), 2.15), 2.16). 2.17) and 2.19). In consequence, it exists significant relationships in those items.

\section{Discussion}

The expansion of SNS around the world is a fact. Thousands of million followers access to platforms such as Facebook, XING, Google+, Linkage and ResearchGate from different places in the planet (Faccin, 2016) changing human communication styles. People exchange resources, comments, and feelings using diverse formats such as videos, pictures (YouTube; Stickam; Instagram, etc.), or shorter instant messages (WhatsApp; Twitters; Snapchat, etc.) using SNS.

It exists an intense global debate related to the effectiveness of SNS in academic context (Sun et al., 2007; Armstrong \& Franklin, 2008; Boyd \& Ellison, 2008; Farhat \& Kazim, 2011; Lucas \& Moreira, 2015). Spanish and Ecuadorian scholars agree in argue that SNS are cyber environments with the power to promote the collaborative learning activities, authentic material exchange, learners' autonomy, and they have overcome the barriers of distance between the global community members (Esteve, 2009; Cabero \& Barroso, 2013; Maiz \& Tejada, 2013; Zapata-Ros, 2014; Moncada \& Freire, 2015; Intriago et al., 2016).

At the same time, Nadkarni and Hofman (2012); and Kirschner (2015) argue that SNS were not designed to be integrated into educational projects, because their real function is to establish global communicational links. To Greenhow, Menzer and Gibbins (2015); and Asterhan and Hever (2015), teachers either students do not know the ways how to use SNS in educational projects so, most of them still only do the traditional click for a "like and dislike". However, in both circumstances (pro or opposition), individuals can use SNS, as tools for English language practice from the commitment of other members having the same willing.

Users can spend hours or even days switched to a SNS. They can exchange racial, sexual, religious, or identities resources since an analytical approach (Boyd \& Ellison, 2008), obtaining unexpected result. SNS could become an addictive practice related to multiple and diverse information available on the Internet. In Addition, risks are still persistent on Internet (cyber bulling, virus infections, etc.) for that reason, every SNS educational project should install monitoring controllers and follow ethical policies. Finally, learners consider SNS are not supplying quality material for their foreign language practice. However, it is necessary to remember that, SNS contents are the results of members' participation. The uploading of creative academic videos and lessons on YouTube channels (Temprano, 2011) is an example of the multiple uses of SNS for improving the vocational training sources on internet (Fernandes \& Torres, 2015).

\section{Conclusions}

The interest of this work, beyond the assessment of learners' attitudes toward English language practice on Social Network Sites, is also to contribute to the global discussion about the digital competences for improving the use of SNS in a higher education context. Here, we introduce our conclusions:

It is recognised that human attitudes have the power to change people perception and reactions. Then, any educational project on ICT, should consider during their design the learners' digital competences but also, their attitudes toward Social Networks Sites. Thus, in this work were found relevant relationships between the factors learners' age and country with their individual attitudes for English practice on SNS.

Spanish and Ecuadorian university students prefer using YouTube, and Google + during their language practices because, SNS easy access and flexibility to strengthen listening, reading and comprehension skills. In addition, Facebook, and WhatsApp can be used to motivate reading, writing, and speaking practices in English.

When SNS overcome the distances between their members, it is offer the opportunity for improving learners' social participation and inclusion on a creative and attractive way. Thus, we are before new scenarios that promote and motivate the social knowledge construction but, it is temporarily limited to the users' internet connectivity possibilities.

Finally, this study also introduces the licker questionnaire "Attitudes for language practices through Social Network Sites" developed by Villafuerte and Romero (2016) as a contribution to improve the foreign language acquisition process. 


\section{References}

Aguaded, I. (2013). El Programa «Media» de la Comisión Europea, apoyo internacional a la educación en medios. Comunicar No. 30.

Ahmad, A. (2011). A Short Description of Social Networking Websites and Its Uses. International Journal of Advanced Computer Science and Applications, 2(2). https://doi.org/10.14569/IJACSA.2011.020220

Area, M. (2010). The process of integration and the pedagogical use of ICT in schools. Revista de Educación, 352, 77-97. Retrieved February 8, 2017, from http://www.revistaeducacion.educacion.es/re352/re352_04.pdf

Armstrong, J., \& Franklin, T. (2008). A review of current and developing international practice in the use of social networking (Web 2.0) in higher education. Retrieved February 7, 2017, from http://www.franklin-consulting.co.uk/LinkedDocuments/the\%20use $\% 20 \mathrm{of} \% 20$ social\%20networking\%20in \%20HE.pdf

Asterhan, C., \& Hever, R. (2015). Learning from reading argumentative group discussions in Facebook-Rhetoric style matters. Computers in Human Behavior, 53, 570-576. https://doi.org/10.1016/j.chb.2015.05.020

Bahney, A. (2006). Don't talk to invisible strangers. In New York Times. Retrieved January 27, 2017, from http://www.nytimes.com/2006/03/09/fashion/thursdaystyles/dont-talk-to-invisible-strangers.html

Beck, A. (2007). Web 2.0: Konzepte, Technologie, Anwendungen.

Boyd, D. (2008). Why youth heart social network sites: The role of networked publics in teenage social life. In D. Buckingham (Ed.), Youth, Identity, and Digital Media (pp. 119-142). Cambridge, MA: MIT Press. Retrieved from http://research.fit.edu/sealevelriselibrary/documents/doc_mgr/1006/Boyd. _2008._Why_teens_love_social_media.pdf

Boyd, D., \& Ellison, N. (2008). Social Network Sites: Definition, History, and Scholarship. Journal of Computer-Mediated Communication, 13, 210-230. https://doi.org/10.1111/j.1083-6101.2007.00393.x

Boyd, D., \& Heer, J. (2006). Profiles as Conversation: Networked Identity Performance on Friendster. In Proceedings of the Hawai'i International Conference on System Sciences (HICSS-39). Persistent Conversation Track, Kauai, HI: IEEE Computer Society. Retrieved February 6, 2017, from http://www.danah.org/papers/HICSS2006.pdf

Burgues, C. (2011). Comunidades educativas, de aprendizaje y aprendizaje cooperativo: Puntos comunes y divergentes.

Cabero, J. (2005). Las TIC y las universidades: Retos, posibilidades y preocupaciones. Revista de la Educación Superior, XXXIV(3), 77-100. Retrieved February 8, 2017, from http://tecnologiaedu.us.es/images/stories/jca57.pdf

Cabero, J. (2009). Tendencies for Digital Learning: From Readymade Content to Activity Centred Material Design.The Dipro 2.0 Project. Revista de Educación a Distancia, 32. Retrieved February 9, 2017, from http://www.um.es/ead/red/32/cabero.pdf

Cabero, J., Barroso, J., Llorente, M. ${ }^{a}$ C., \& Marín, V. (2013). Las redes sociales como instrumento para la formación. Percepciones de los alumnos universitarios hacia el trabajo en grupo. Sevilla: Grupo de Investigación Didáctica, Universidad de Sevilla.

Cevallos, I., Intriago, E., Villafuerte. J., Molina, G., \& Ortega, L. (2017). Motivation and Autonomy in Learning English as Foreign Language: A Case Study of Ecuadorian College Students. English Language Teaching, 10(2).

Coll, C., Mauri, T., \& Onrubia, J. (2008). Analyzing Actual Uses of ICT in Formal Educational Contexts: A Socio-Cultural Approach. Revista Electrónica de Investigación Educativa, 10(1), 1-18. Retrieved February 7 , 2017, from http://redie.uabc.mx/redie/article/view/177

CRUE. (2011). UNIVERSITIC2011: Descripción, gestión y gobierno de las TIC en el sistema Universitario Español. $\quad$ Retrieved $\quad$ March $\quad 12, \quad 2017, \quad$ from http://www.crue.org/Documentos\%20compartidos/Publicaciones/Universitic/Universitic_2011.pdf

Cundill, G. (2010). Monitoring social learning processes in adaptive comanagement: Three case studies from South Africa. Ecology and Society, 15(3), 28. https://doi.org/10.5751/ES-03467-150328

En Vallés, J., Álvarez, D., \& Rickenmann del Castillo, R. (2011). L'Activitat docent: Intervenció, innovació, información (pp. 241-248). Documenta Universitaria, España. 
Estadista.com. (2015). Ranking de los 20 países que más accedieron a redes sociales desde un smartphone a nivel mundial en 2015 (porcentaje de usuarios). Retrieved February 2, 2017, from https://es.statista.com/estadisticas/655296/usuarios-globales-que-accedieron-a-redes-sociales-desde-moviles -por-pais/

Esteve, F. (2009). Bolonia y las TIC: De la docencia 1.0 al aprendizaje 2.0. In Revista La cuestión universitaria (No. 5, pp. 59-68). Retrieved February 22, 2017, from http://www.anobium.es/docs/gc_fichas/doc/LRSPFDzlbc.pdf

European Commission/EACEA/Eurydice. (2015). The European Higher Education Area in 2015: Bologna Process Implementation Report. Luxembourg: Publications Office of the European Union. Retrieved February 9 , 2017 , from $\mathrm{http} / / /$ eacea.ec.europa.eu/education/eurydice/documents/thematic_reports/182EN.pdf

Faccin, J. (2016). The most important Social Networks in the World-Updated list 2016. Retrieved February 5, 2017, from http://josefacchin.com/lista-redes-sociales-mas-importantes-del-planeta/

Farhat, J., \& Kazim, S. (2011). The Role of Culture in ELT: Learners' Attitude towards the Teaching of Target Language Culture. European Journal of Social Sciences, 23(4). Retrieved February 19, 2017, from https://www.researchgate.net/profile/Farhat_Jabeen7/publication/260045647_The_Role_of_Culture_in_EL T_Learners\%27_Attitude_towards_the_Teaching_of_Target_Language_Culture/links/0c96052f3541a25ccc 000000/The-Role-of-Culture-in-ELT-Learners-Attitude-towards-the-Teaching-of-Target-Language-Culture. pdf

Fasol, R. (2005). The Sociolinguistics of Society. Research gate. Retrieved February 14, 2017, from https://www.researchgate.net/publication/243781600_The_Sociolinguistics_of_Society

Fernandes, J. M., \& Bermejo, B. (2012). Teachers' attitudes toward ICT in good practice teaching, in schools with inclusive orientation. Enseñanza \& Teaching, 30, 45-61. Retrieved February 11, 2017, from https://idus.us.es/xmlui/bitstream/handle/11441/49099/Actitudes\%20docentes\%20hacia\%20las\%20TIC\%2 0en $\% 20$ centros $\% 20 \mathrm{de} \% 20$ buenas\%20practicas\%20educativas\%20con\%20orientacion\%20inclusiva.pdf?se quence $=1 \&$ is Allowed $=\mathrm{y}$

Fernandez, J. M., \& Torres, J. A. (2015). Teacher attitudes and best practices with ICT faculty Adult Continuing Education in Andalusia. Revista Complutense de Educacion, 26, 33-49. Retrieved February 7, 2017, from http://revistas.ucm.es/index.php/RCED/article/view/43812/45930

Gobierno de Ecuador. (2011). Fortalecimiento del Inglés, Objetivos. En Ministerio de Educación (Oficio Nro. SENPLADES-SIP-dap-2011-655; CUP91400000.0000.372704). Retrieved June 8, 2017, from https://educacion.gob.ec/objetivos-2/

Gonzalez, P. (2012). La asombrosa historia de Kevin Systrom, fundador de Instagram. Retrieved February 2, 2017 , from http://instagramers.com/spanish/la-asombrosa-historia-de-kevin-systrom-fundador-de-instagram/

Greenhow, C., Menzer, M., \& Gibbins, T. (2015). Re-thinking scientific literacy: Arguing science issues in a niche Facebook application. Computers in Human Behavior, 53, 593-604. https://doi.org/10.1016/j.chb.2015.06.031

Halliday, M. (2014). Introduction to functional grammar. In Routledge (4th ed.). Retrieved February 9, 2017, from https://www.google.es/search?q=Halliday\%2C+M.+(2005).+On+grammar\&ie=utf-8\&oe= utf-8\&client=firefox-b\&gfe_rd=cr\&ei=IIOdWPufIMip8weUkY_IDQ

Interactivity.org. (2007). Twitter: Qué es y para qué sirve? Retrieved February 2, 2017, from http://www.interactividad.org/2010/01/26/twitter-\%C2\%BFque-es-y-para-que-sirve/

Intriago, E., Morales, M. A., \& Soto, S. (2015). Approaches to EFL Teaching: Curriculum, Culture, Instruction, Assessment, \& Tech. Retrieved 2016, from http://webcache.googleusercontent.com/search?q=cache:6E4YDQDj1xIJ:repositorio.utmachala.edu.ec/bitst ream/48000/6886/1/108\%2520APPROACHES\%2520TO\%2520EFL\%2520TEACHING\%25204.pdf+\&cd $=3 \& \mathrm{hl}=\mathrm{en} \& \mathrm{ct}=\mathrm{clnk} \& \mathrm{gl}=\mathrm{es}$

Intriago, E., Villafuerte, J., \& Morales, M. (2016). Google apps for virtual learning communities development: Strengthening english language skills in an university environment. Revista AtoZ, 5(1). Retrieved December 12, 2016, from http://revistas.ufpr.br/atoz/article/view /45170/28363 
Jansen, D. (2010). Soziales Netzwerk. In The Impact of Social Networking Sites on the Employer-Employee Relationship. $\quad$ Retrieved December $\quad 9, \quad 2016$, from https://domino.fov.uni-mb.si/proceedings.nsf/0/629623964b656aadc12578f900813f07/\$FILE/P19_Martens en.pdf

Kirschner, P. (2015). Facebook as learning platform: Argument superhighway or dead-end street. Computers Human Behavior, 53, 621-625. https://doi.org/10.1016/j.chb.2015.03.011

Krashen, S. (2004). The Power of Reading. Insights from research. British Library. USA.

Lucas, M., \& Moreira, A. (2015). Using ICT to promote teachers' competences: Strategies and challenges. EAI Endorsed Transactions on e-Learning, 15(5), e1. https://doi.org/10.4108/el.2.5.e1

Maiz, I., \& Tejada, E. (2013). La utilización de las redes sociales desde una perspectiva educativa en Ana Vásquez-Martínez y Julio Cabero-Almenara (2014). Las redes sociales aplicadas a la formación. Retrieved October 26, 2016, from http://revistas.ucm.es/index.php/RCED/article/view/47078/45942

Martensen, M., Börgmann, K., \& Bick, M. (2011). The Impact of Social Networking Sites on the Employer-Employee Relationship. In 24th Bled eConference eFuture: Creating Solutions for the Individual, Organisations and Society. Retrieved 2016, from http://revistas.ucm.es/index.php/RCED/article/view/47078/45942https://domino.fov.uni-mb.si/proceedings. nsf/0/629623964b656aadc12578f900813f07/\$FILE/P19_Martensen.pdf

Moncada, R., \& Freire, R. (2015). El vínculo de los jóvenes entre 14 y 18 años de Quito, Ecuador con las redes sociales.

Muro, M., \& Jeffrey, P. (2008). A critical review of the theory and application of social learning in participatory natural resource management. Journal of Environmental Planning and Management, 51, 325-344. https://doi.org/10.1080/09640560801977190

Nadkarni, A., \& Hofman, S. (2012). Why do people use facebook? National Institute of Health. Retrieved February 9, 2017, from https://www.ncbi.nlm.nih.gov/pmc/articles/PMC3335399/

Piccoli, G., Ahmad, R., \& Ives, B. (2001). Web-Based Virtual Learning Environments: A Research Framework and a Preliminary Assessment of Effectiveness in Basic IT Skills Training. MIS Quarterly, 25(4), 401-426. https://doi.org/10.2307/3250989

Reed, M., Evely, C., Cundill, G., Fazey, I., Glass, J., Laing, A., ... Stringer, L. (2010). What is social learning? Ecology and Society. Retrieved February 6, 2017, from https://researchrepository.standrews.ac.uk/bitstream/handle/10023/1624/Fazey2010EcologySociety15WhatI sSocialLearning.pdf? sequence $=1 \&$ isAllowed $=\mathrm{y}$

Ricoy, M. C., \& Couto, M. J. (2012). The approach to the professional context as a motive to investigate about ICT: A qualitative study. Revista Complutense de Educación, 23(2), 443-446. Retrieved February 7, 2017, from https://revistas.ucm.es/index.php/RCED/article/download/40037/38475+\&cd=1\&hl=en\&ct=clnk\&gl=es\&cl ient $=$

Sainz, L. (2014). Facebook, 10 años de "Me gusta". Retrieved February 2, 2017, from http://www.eitb.eus/es/noticias/tecnologia/detalle/1961318/facebook-aniversario--cuando-nacio-quien-lo-cr eo

Salinas, J. (2001). El rol del profesor en la transicion de la enseñanza presencial al aprendizaje on line.

Schalk, A. (2010). El impacto de las TIC en la educación. Retrieved February 3, 2017, from http://unesdoc.unesco.org/images/0019/001905/190555s.pdf

Seely, J. (2012). Symposium and public lecture. In Learning in and for the 21st Century. Retrieved February 22, 2017, from http://www.johnseelybrown.com/CJKoh.pdf

Sun, P., Tsai, R., Finger, G., Chen, Y., \& Yeh, D. (2007). What drives a successful e-Learning? An empirical investigation of the critical factors influencing learner satisfaction. In Computers and Education. Retrieved January 9, 2017, from http://www.water-msc.org/en/knowledge_base/successful_e_learning.pdf

Temprano, A. (2011). Las TIC en la enseñanza bilingüe. Recursos prácticos para la creación de actividades interactivas y motivadoras, Editorial Mad, Eduforma, España.

Thomas, D., \& Brown, J. (2011). A new culture of learning. Retrieved December 9, 2016, from http://www.newcultureoflearning.com/newcultureoflearning.pdf 
Tudu, P. N., \& Pathak, P. (2015). Social Network Sites: Can they enhance Employee Productivity in an organization? The International Journal of Management Science and Information Technology (IJMSIT), 17, 23-35. Retrieved January 4, 2017, from http://www.naisit.org/journal/download-paper/id/504

UNESCO. (2015). 17 Goals to transform our world. Retrieved December 3, 2016, from http://www.un.org/sustainabledevelopment/

Vaynerchuck, G. (2016). La historia de Snapchat, la nueva rompecorazones de las marcas, en 15 hitos. Retrieved December 1, 2016, from https://www.marketingdirecto.com/digital-general/social-media-marketing/historia-snapchat-nueva-rompec orazones-marcas-en-15-hitos

Villafuerte, J., Carreño, M., \& Demera, J. (2015). Calidad e innovaciones para potenciar la enseñanza de lenguas extranjeras usando la red s. Facebook. Revista investigacion y sabers, 3(4). Retrieved from http://www.utelvt.edu.ec/ojs/index.php/is/article/view/110

Wellman, B. (1996). An Electronic Group is Virtually a Social Network. Retrieved February 6, 2017, from https://pdfs.semanticscholar.org/40e1/07eaf3b1378bccb7f7e0398b01293a5ee022.pdf

Zapata, M. (2014). Gestión del aprendizaje en Educación Superior y web social. In RED, Revista de Educación a Distancia. Número 42, Número monográfico sobre "Experiencias y tendencias en affordances educativas de campus virtuales universitarios". Retrieved February 7, 2017, from http://www.um.es/ead/red/42/zapata.pdf

\section{Copyrights}

Copyright for this article is retained by the author(s), with first publication rights granted to the journal.

This is an open-access article distributed under the terms and conditions of the Creative Commons Attribution license (http://creativecommons.org/licenses/by/4.0/). 